\title{
Production Potential, and Energetic Studies as Affected by Pigeon pea (Cajanus cajan L.) and Finger millet (Eleusine coracana L.) Intercropping System
}

\author{
Sunita Kujur, Md. Naiyar Ali*, R.K. Lakra and S. Ahmad \\ Department of Agronomy, Birsa Agricultural University, Kanke, \\ Ranchi-834006, Jharkhand, India \\ *Corresponding author
}

\section{A B S T R A C T}

Pigeon pea (Cajanus cajan L.) is grown in rainfed as well as dry region of India, growing of only pulses is not so much remunerative in present scenario of dry areas of agriculture to fulfill the diverse demand of consumers and rapid growing population. A field experiments was conducted during the Kharif seasons of 2005 and 2006 at Birsa

\section{Keywords}

Energetic, Yield attributes, Yield, Net return, Intercropping, Finger millet, Pigeon pea

\section{Article Info}

Accepted: 20 December 2017 Available Online: 10 January 2018 Agricultural University Farm, Ranchi, Jharkhand to assess the energetics and production potential of pigeon pea (Cajanus cajan L.) in sole and intercropping with different duration (short, medium, and long) cultivars of finger millet under 1:1, 1:2, 1:3 and 1:4 row proportions. Sole crops of pigeon pea and finger millet always showed highest yield attributes that decreased due to intercropping with different duration cultivars of finger millet and number of rows of finger millet. Pods plant ${ }^{-1}$, seeds pod $^{-1}$ and 100 seed weight of pigeon pea and ears $\mathrm{m}^{-1}$ row length, seeds ear $^{-1}$ and test weight of finger millet were recorded higher under pigeon pea and finger millet intercropping system in 1:1 row ratio and reduced in 1:4 row ratio. The maximum grain yield $10.9 \mathrm{qha}^{-1}$ was obtained with pigeon pea sole which was significantly superior to intercropping systems. Grain yield of pigeon pea increased with decreased in row ratio of finger millet and grain yield of finger millet increased when row ratio of finger millet increased. The maximum pigeon pea equivalent yield i.e. $13.13 \mathrm{qha}^{-1}$, net returns (Rs. 15090.5 ha-1) and benefit: cost ratio (2:31) was recorded when pigeon pea intercropped with finger millet in 1: 1 row combination with short duration cultivars of finger millet. When row ratio of finger millet increased energy use efficiency and net energy output of biomass increased and specific energy was decreased irrespective of all the cultivars.

\section{Introduction}

Intercropping is a potentially beneficial system, shows substantial yield advantage over sole cropping and reduces risk. This advantage can be achieved not by means of costly inputs but by simple expedient of growing crops together (Willey, 1979). Intercropping especially cereal with legume combination can increase production and productivity by better utilization of resources and there by minimizes the risks and brings stability under rainfed conditions. Finger millet is an important coarse cereal of tropical 
climate, grown mostly under rainfed and short drought spell situation in poor and marginal soils of hill as well as arid and semi-arid region of the country. Finger millet has strong compensatory ability in terms of tiller production.

The adjustment ability of finger millet crop under wide range of row spacing and plant population makes it a suitable choice of intercropping with pigeon pea. An improved short and medium duration finger millet cultivars in place of long duration finger millet which can give more yield, will be an ideal option of intercropping with pigeon pea. Being a short duration crop, its timely sowing and early harvesting it may ensure sufficient residual moisture in the soil which can be well utilized by the companion crop with dissimilar rooting system as well as canopy structure.

With the development of Indian Agriculture, crop production and rural agro-processing has emerged as one of the major consumer of commercial energy. In recent day of energy crisis, a crop scientist aims to harvest maximum energy from crop in a cropping system with minimum energy requirement. Energy input increases with increase in cropping intensity and it varies with the nature of component crops. Higher energy requirement of cereals than grain legumes/oilseeds is due to mainly to higher requirement of nutrient, water and physical energy animal, manual and efficiently per unit area per unit time there by produces more energy per unit of energy input (Verma et al., 1994).

Crop production directly related to the optimum use management of energy inputs (seed, fertilizer, irrigation, labours etc.) to increase productivity. The cost of these inputs are increasing day by day. Therefor energetics analysis has become an important aspect for planting of crop production system.

\section{Materials and Methods}

A field experiments was conducted during two consecutive kharif season of 2005 and 2006 at Birsa Agricultural University Farm, Ranchi, Jharkhand to study the effect of different row ratio and cultivars of finger millet on productivity and economics. The experimental soil was sandy loam having $\mathrm{pH} 5.55$, low in available $\mathrm{N}\left(190.2 \mathrm{~kg} \mathrm{ha}^{-1}\right)$ and $\mathrm{P}(10.65 \mathrm{~kg}$ $\left.\mathrm{ha}^{-1}\right)$ and medium in available $\mathrm{K}(145.0 \mathrm{~kg}$ $\left.\mathrm{ha}^{-1}\right)$. The sixteen treatments consisted of pigeon pea BR-65 (180-200 days duration) as base crop and three cultivars of finger millet short duration (SD) Birsa Marua -1 (85-95 days duration), medium duration (MD) HR374 (105-115 days duration) and long duration (LD) PR-202 (120-130 days duration) taken as sole as well as intercrops in four row ratios $(1: 1,1: 2,1: 3$ and $1: 4)$ were laid out in RBD with three replications. In pigeon pea sole full dose of fertilizers (25-22.0-20.8 kg N-P-K $\mathrm{ha}^{-1}$ ) was applied at the time of sowing. While Sole crop of finger millet and pigeon pea + finger millet intercropping system, $25 \mathrm{~kg}$ additional $\mathrm{N}$ was applied 30 days after sowing. Two weeding were done at 15 and 30 days after sowing. At the time of sowing, $0.3 \mathrm{t} \mathrm{ha}^{-1}$ of lime was applied in furrows of pigeon pea to neutralized local zone $\mathrm{pH}$ of the soil. Crops were sown in $1^{\text {st }}$ week of July in both the year of experimentation. During crop period from July to December about $830.5 \mathrm{~mm}$ and $1292.9 \mathrm{~mm}$ rainfall were received in 2005 and 2006, respectively. Pigeon pea equivalent yield was worked out by converting the yields of intercrops to the yield of pigeon pea on the basis of prevailing market price of each crop. The economics of different crops and crop combinations were computed on the basis of prevailing market rates of produce and agro inputs. Energy input of each treatment was calculated from recorded data for each component of operations as expressed in Mega Jule (MJ) / ha taking standard values suggested by Panesar and Bhatnagar (1994). 
Similarly, energy output by grain and straw yield ( $\mathrm{kg} / \mathrm{ha})$ of each treatment was also converted into energy unit. The energy - use efficiency based on output; input energy ratio was determined to assess the efficiency of nutrient management practices. Specific energy MJq-1) was calculated by dividing input energy by the corresponding grain equivalent yield.

\section{Results and Discussion}

\section{Yield attributes}

Sole crops of pigeon pea and finger millet always showed highest yield attributes that decreased due to intercropping with different duration cultivars of finger millet and number of rows of finger millet (Table 1). Pods plant ${ }^{-1}$, seeds pod $^{-1}$ and 100 seed weight of pigeon pea were recorded maximum under sole condition. In intercropping systems, maximum yield attributes were recorded under pigeon pea + finger millet (SD) 1:1 row ratio and the lowest value in long duration finger millet at 1: 4 ratio. It might be due to varying competition between component crop for light, moisture, nutrient and space with increase in plant density. More reduction in yield attribute of pigeon pea were found when it was intercropped with long duration finger millet and less with medium and short duration finger millet cultivars. This may be attributed to smothering and more competitive effect of long duration finger millet for longer period of pigeon pea.

The yield attributes of finger millet like ears $\mathrm{m}^{-1}$ row, seeds ear ${ }^{-1}$ and test weight were reduced by 14.7, 23.1, and 4.6 per cent in Long duration,22.77,18.36 and 1.28 in Medium duration and $21.31,16.29$ and 2.25 per cent in Short duration cultivars, respectively in intercropping with pigeon pea under 1:4 row proportion. This was due to intense competitative effect of greater population pressure of finger millet on lesser population of pigeon pea. Non-significant reduction in yield attributing characters of finger millet in short, medium and long duration cultivars was observed due to less shading effect of pigeon pea. Similar findings were also reported by Maitra et al., (2000).

\section{Grain and stalk/ straw yield}

The maximum grain and stalk/ straw yield of pigeon pea and finger millet was recorded under sole cropping when compared to intercropping systems (Table 2). Under intercropping system, maximum grain and stalk yield of pigeon pea was obtained under pigeon pea + finger millet (short duration) 1:1 row ratio followed by pigeon pea + finger millet (medium duration) 1:1 row ratio as compared to other row combinations. It may be due to wider spacing of intercrop compared to other row arrangement facilitating effective sharing of growth resources with finger millet to get higher grain yield. Among finger millet cultivars, intercropping of short duration cultivars produced higher grain and stalk yield of pigeon pea irrespective of row proportion. It may be due to minimum competition between pigeon pea with short duration cultivar of finger millet at initial growth period. Short duration finger millet is fast growing as compared to pigeon pea. At 90 days of crop growth, pigeon pea attainded their reproductive period and at this period short duration finger millet attended their harvesting stage. Therefore, no competition between pigeon pea and short duration finger millet at reproductive period and that was the reason for higher yield. While the long duration cultivar of finger millet recorded the higher grain and straw yield irrespective of row proportion as they get more time to complete their life cycle facilitating better vegetative growth and mobilization of assimilates source to sink. It was interesting to note that when row ratio of finger millet 
increased in pigeon pea + finger millet intercropping system, yield of finger millet increased due to higher plant densities and yield of pigeon pea was decreased due to competition effect of higher plant densities of finger millet. This is in conformity with the findings of Mahto et al., (2007) who reported that intercropping with decreased plant density of finger millet in association with pigeon pea resulted in higher grain yield of pigeon pea.

\section{Pigeon pea equivalent yield}

Data recorded on pigeon pea equivalent yield revealed that pigeon pea in association with finger millet recorded maximum pigeon pea equivalent yield with pigeon pea + finger millet (SD) 1:1 (13.13 q ha $\mathrm{q}^{-1}$ ) row proportion followed by pigeon pea + finger millet (MD) $1: 1\left(12.92 \mathrm{q} \mathrm{ha}^{-1}\right)$ row proportion may be due to higher yield of pigeon pea and higher value of pigeon pea in alternate row intercropping system (Table 2). Higher pigeon pea equivalent yield in intercropping system may be attributed to slow growing habit and temporal differences between the pigeon pea and finger millet intercrop, difference in growth habit and rooting pattern made both crops suitable for intercropping in alternate row system. Similar finding was also observed by Kumar et al., (2009) in Pigeon pea + little millet intercropping system. The short duration finger millet due to initial better growth, suffered less competition from pigeon pea. While long duration finger millet in 1:1 row proportion recorded comparatively lower yield as part of its grand growth coincided with the grand growth period of pigeon pea which adversely affected the growth and development of associated pigeon pea. Intercropping of pigeon pea with finger millet in 1:4 row proportion in all the three cultivars of long, medium and short duration of finger millet gave lower pigeon pea equivalent yield (10.23-LD, 9.39-MD and 9.33 qha-1-SD) compared to sole crop of pigeon pea (10.9 qha-1) owing to more interspecies competition of component crops, resulting in reduction in pigeon pea yield.

\section{Economic}

Pigeon pea+ finger millet (SD) 1:1 row proportion produced maximum net returns (Rs. $15090.5 \mathrm{ha}^{-1}$ ) and Benefit : cost ratio (2:31) which was comparable to pigeon pea + finger millet $(\mathrm{MD})$ 1:1, pigeon pea + finger millet (LD) 1:1 and pigeon pea + finger millet (SD) 1:2 row ratio in intercropping system, respectively but significantly superior to rest of the systems (sole and intercropping) mainly owing to higher production and lower cost of cultivation in these systems. This is in conformity with the result of Ramamoorthy et al., 2004. However, minimum net return and benefit: cost ratio were obtained with pigeon pea and finger millet in 1: 4 row ratio irrespective of duration of finger millet cultivars.

\section{Energetics under different systems}

\section{Energy input}

In sole cropping system maximum energy input (5218 $\mathrm{MJ} \mathrm{ha}^{-1}$ ) was recorded under finger millet (LD) sole in comparison to finger millet (MD) sole and finger millet (SD) sole ((Table 3). However, minimum energy input (3855 MJ ha ${ }^{-1}$ ) was recorded under sole pigeon pea. In intercropping system, maximum energy input (5992 $\mathrm{MJ} \mathrm{ha}^{-1}$ ) was recorded with pigeon pea +finger millet (LD) 1:4 row ratio perhaps due to higher energy input through human and animal labour, seed, fertilizer and chemicals energy. In general, the energy consumption was substantially lower in sole cropping than in intercropping, though the lowest energy consumed when either legumes grown under sole cropping. These results are in agreement with the observations of Pathi and Panigrahi (2006). 
Table.1 Yield attributes of pigeon pea and finger millet as influenced by treatments (pooled data of 2 years)

\begin{tabular}{|c|c|c|c|c|c|c|c|c|}
\hline \multirow[t]{2}{*}{ Treatments } & \multicolumn{3}{|c|}{ Pigeon pea } & \multicolumn{5}{|c|}{ Finger millet } \\
\hline & $\begin{array}{l}\text { Pods } \\
\text { plant }^{-1}\end{array}$ & $\begin{array}{l}\text { Seeds } \\
\operatorname{pod}^{-1}\end{array}$ & 100 seed $(g)$ & $\begin{array}{c}\text { Effective } \\
\text { tillers } \\
\text { m }^{-1} \text { row }\end{array}$ & $\begin{array}{l}\text { Length } \\
(\mathrm{cm}) \text { ear }^{-1}\end{array}$ & $\begin{array}{l}\text { Fingers } \\
\text { ear }^{-1}\end{array}$ & Seeds ear ${ }^{-1}$ & $\begin{array}{c}1000 \\
\text { seeds wt. } \\
(\mathrm{g})\end{array}$ \\
\hline Pigeon pea(PP) sole & 129.99 & 3.37 & 8.09 & - & - & - & - & - \\
\hline $\begin{array}{ll}\text { Finger } & \text { millet } \\
(\text { FM,LD) sole } & \end{array}$ & - & - & - & 27.90 & 7.67 & 6.74 & 1865 & 3.23 \\
\hline $\begin{array}{l}\text { Finger millet } \\
(F M, M D) \text { sole }\end{array}$ & - & - & - & 27.44 & 7.04 & 6.40 & 1835 & 3.13 \\
\hline $\begin{array}{ll}\text { Finger } & \text { millet } \\
(\text { FM,SD) sole } & \end{array}$ & - & - & - & 27.77 & 6.24 & 6.99 & 1756 & 3.11 \\
\hline PP +FM (LD) 1:1 & 63.51 & 3.18 & 7.90 & 26.91 & 6.98 & 6.60 & 1769 & 3.24 \\
\hline PP +FM (LD) 1:2 & 57.95 & 3.08 & 7.75 & 26.54 & 6.94 & 6.31 & 1661 & 3.15 \\
\hline PP +FM (LD) 1:3 & 47.48 & 2.93 & 7.67 & 24.25 & 7.18 & 6.26 & 1555 & 3.14 \\
\hline PP +FM (LD) 1:4 & 37.16 & 2.89 & 7.55 & 23.79 & 7.30 & 6.03 & 1435 & 3.08 \\
\hline PP+FM (MD) 1:1 & 76.13 & 3.21 & 7.91 & 25.55 & 7.12 & 6.59 & 1818 & 3.34 \\
\hline PP+FM (MD) 1:2 & 63.29 & 3.05 & 7.81 & 24.64 & 7.49 & 6.52 & 1710 & 3.23 \\
\hline PP+FM (MD)1:3 & 55.54 & 2.98 & 7.76 & 22.25 & 7.54 & 6.34 & 1623 & 3.27 \\
\hline PP+FM (MD) 1:4 & 43.33 & 2.95 & 7.61 & 21.19 & 7.55 & 6.01 & 1498 & 3.09 \\
\hline PP +FM (SD) 1:1 & 82.51 & 3.25 & 7.93 & 25.49 & 6.90 & 7.39 & 1789 & 3.21 \\
\hline PP +FM (SD) 1:2 & 69.34 & 3.13 & 7.83 & 24.78 & 7.04 & 7.32 & 1681 & 3.22 \\
\hline PP+FM (SD) $1: 3$ & 58.14 & 3.05 & 7.74 & 23.42 & 7.46 & 6.82 & 1588 & 3.14 \\
\hline PP +FM (SD) $1: 4$ & 45.76 & 2.95 & 7.64 & 21.85 & 7.83 & 6.54 & 1470 & 3.04 \\
\hline SEm+ & 3.01 & 0.17 & 0.17 & 1.15 & 0.32 & 0.00 & 84.01 & 0.30 \\
\hline $\mathrm{CD}(\mathrm{P}=0.05)$ & 8.83 & NS & NS & 3.34 & NS & NS & 244.62 & NS \\
\hline
\end{tabular}

LD - Long duration, MD - Medium duration, SD - Short duration, PP: Pigeon pea, FM: Finger millet 
Table.2 Pigeon pea grain, stalk/straw yield, pigeon pea equivalent yield and economics as influenced by treatments (Pooled mean of 2 years)

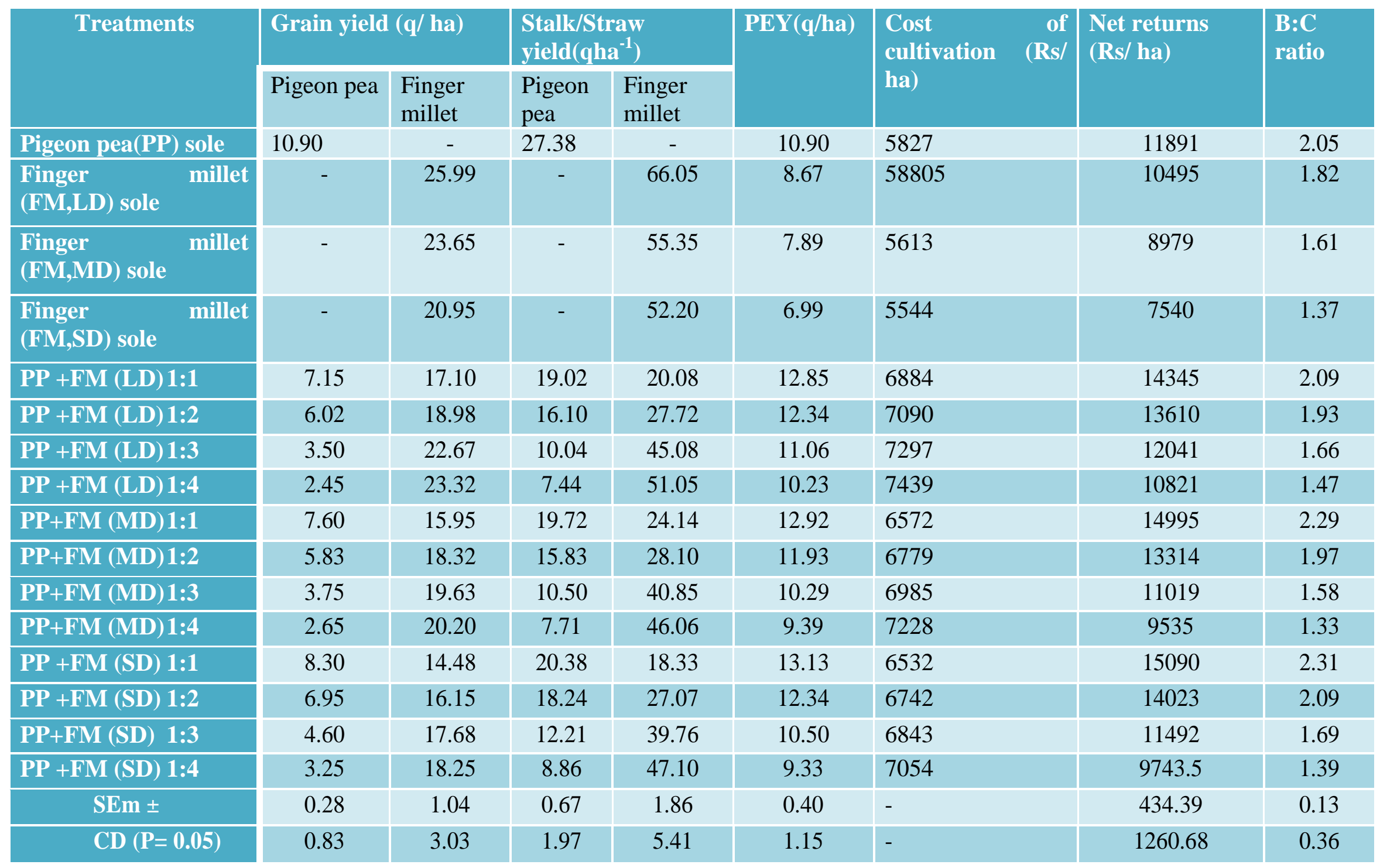


Table.3 Energy input \&output, gross energy output, energy use efficiency and specific energy, as influenced by treatments (Pooled mean of 2 years)

\begin{tabular}{|c|c|c|c|c|c|c|c|c|}
\hline \multirow[t]{2}{*}{ Systems } & \multirow[t]{2}{*}{$\begin{array}{l}\text { Energy input } \\
\left(\mathrm{MJha}^{-1}\right)\end{array}$} & \multicolumn{2}{|c|}{$\begin{array}{l}\text { Gross energy output (MJha } \\
\text { 1) }^{-}\end{array}$} & \multicolumn{2}{|c|}{ Net energy output (MJha $\left.{ }^{-1}\right)$} & \multicolumn{2}{|c|}{ Energy use efficiency } & \multirow[t]{2}{*}{$\begin{array}{l}\text { Specific energy } \\
(\mathrm{MJq}-1)\end{array}$} \\
\hline & & Grain & Biomass & Grain & Biomass & Grain & Biomass & \\
\hline Pigeon pea(PP) sole & 3855 & 16023 & 65298 & 12168 & 61443 & 4.16 & 16.94 & 354.18 \\
\hline $\begin{array}{ll}\text { Finger } & \text { millet } \\
(F M, L D) \text { sole }\end{array}$ & 5218 & 38212 & 120775 & 32994 & 115557 & 7.33 & 23.15 & 603.11 \\
\hline $\begin{array}{ll}\text { Finger } & \text { millet } \\
(\text { FM,MD) sole } & \end{array}$ & 5185 & 34765 & 103953 & 29580 & 98768 & 6.71 & 20.05 & 661.68 \\
\hline $\begin{array}{ll}\text { Finger } & \text { millet } \\
(\text { FM,SD) sole } & \end{array}$ & 5175 & 30061 & 95311 & 24900 & 90136 & 5.81 & 18.42 & 761.08 \\
\hline PP+FM(LD)1:1 & 5577 & 35647 & 94977 & 30071 & 89401 & 6.39 & 17.04 & 434.06 \\
\hline PP+FM (LD) 1:2 & 5618 & 36735 & 100359 & 31117 & 94741 & 6.49 & 17.86 & 455.34 \\
\hline PP +FM (LD) 1:3 & 5975 & 38462 & 112878 & 32488 & 106904 & 6.44 & 19.97 & 540.49 \\
\hline PP +FM (LD) 1:4 & 5992 & 37882 & 120087 & 31890 & 114095 & 6.37 & 21.15 & 586.02 \\
\hline PP+FM (MD)1:1 & 5528 & 34618 & 100290 & 29091 & 94762 & 6.27 & 18.15 & 428.07 \\
\hline PP+FM (MD) 1:2 & 5580 & 35493 & 99104 & 29913 & 93524 & 6.37 & 17.76 & 467.94 \\
\hline PP+FM (MD) 1:4 & 5623 & 33589 & 105042 & 27967 & 99420 & 5.96 & 18.68 & 599.47 \\
\hline PP +FM (SD) 1:1 & 5488 & 33479 & 93061 & 27992 & 87573 & 6.10 & 16.96 & 418.28 \\
\hline PP +FM (SD) 1:2 & 5555 & 33957 & 100538 & 28402 & 95072 & 6.12 & 18.12 & 450.64 \\
\hline PP+FM (SD) $1: 3$ & 5588 & 32744 & 104422 & 27156 & 98834 & 5.87 & 18.69 & 533.14 \\
\hline PP +FM (SD) 1:4 & 5612 & 31605 & 106419 & 25993 & 100807 & 5.65 & 18.93 & 601.81 \\
\hline SEm \pm & - & - & - & 1905.9 & 7166.3 & 0.34 & 0.84 & 20.90 \\
\hline $\mathrm{CD}(\mathrm{P}=0.05)$ & - & - & - & 5531 & 20798 & 0.99 & 2.44 & 60.67 \\
\hline
\end{tabular}

LD-Long duration; MD- Medium duration; SD- Short duration 
It was interesting to note that the energy input increasing with increasing row ratio of finger millet under pigeon pea + finger millet intercropping system. Higher value of energy input was obtained under pigeon pea + finger millet intercropping with long duration cultivars of finger millet in comparison to medium and short duration cultivars.

\section{Net energy output}

\section{Grain}

The output energy, however is dependent on yield of component crops. In sole cropping system higher net energy output (32994 MJ ha ${ }^{1}$ ) of grain was obtained with finger millet (LD) sole which was at par with finger millet (MD) sole $\left(29580 \mathrm{MJ} \mathrm{ha}^{-1}\right)$ but significantly superior to finger millet (SD) sole. In intercropping system, pigeon pea + finger millet (LD) 1:3 row ratio recorded maximum net energy output (32488 $\mathrm{MJ} \mathrm{ha}^{-1}$ ) which was at par with all the intercropping system except pigeon pea + finger millet (SD) 1:4 (25993 $\left.\mathrm{MJ} \mathrm{ha}^{-1}\right)$.

\section{Biomass}

Finger millet (LD) sole recorded maximum net energy output (115557 MJ ha ${ }^{-1}$ ) of biomass which was at par with finger millet (MD) sole (98768 $\mathrm{MJ} \mathrm{ha}^{-1}$ ) and significantly superior to finger millet (SD) sole and sole pigeon pea. Minimum net energy output (61443 $\mathrm{MJ} \mathrm{ha}^{-1}$ ) was recorded with pigeon pea sole. In intercropping system, pigeon pea + finger millet (LD) 1:4 row ratio recorded maximum net energy output (114095 $\mathrm{MJ} \mathrm{ha}^{-1}$ ) of biomass which was at par with all the intercropping system except pigeon pea + finger millet (LD) 1:1 (89401 $\mathrm{MJ} \mathrm{ha}^{-1}$ ) and pigeon pea + finger millet (SD) 1:1 (87573 $\mathrm{MJ} \mathrm{ha}^{-1}$ ) row ratio. When row ratio of finger millet increased net energy output of grain and biomass increased and maximum net energy output of biomass was recorded with long duration cultivar of finger millet under pigeon pea + finger millet in 1:4 row ratio in intercropping system.

\section{Energy use efficiency and specific energy as} influenced by system

\section{Grain}

Maximum energy use efficiency (7.33) was obtained with finger millet (LD) sole which was decreased as duration of finger millet decreased. Minimum energy use efficiency (4.16) was recorded with pigeon pea sole. In intercropping system, pigeon pea + finger millet (LD) 1:2 recorded maximum energy use efficiency (6.49) which was statistically alike to all the intercropping treatment combinations. It is interesting to note that energy use efficiency was higher with long duration finger millet (cereal) cultivars in sole as well as intercropping treatment which was decreased with medium and short duration finger millet, respectively. The lowest energy use efficiency was found with sole pigeon pea (legume).

\section{Biomass}

Combined analysis of pooled mean revealed that maximum energy use efficiency (23.15) of biomass was obtained with finger millet (LD) sole which was decreased as duration of finger millet decreased. Minimum energy use efficiency (16.94) of biomass was recorded with sole pigeon pea (legume). In intercropping system, pigeon pea + finger millet (LD) 1:4 row ratio recorded maximum energy use efficiency (21.15) which was on par with pigeon pea + finger millet (LD) 1:3 (19.97) and pigeon pea + finger millet (SD) 1:4 (18.93) and significantly superior to rest of the treatment combinations. It is also clear from the data that as the row ratio of finger millet increased energy use efficiency of biomass increased under pigeon pea + finger millet intercropping system.

\section{Specific energy}

Results obtained from mean value of both the years of experimentation indicated that minimum specific energy (354.18 $\mathrm{MJ} \mathrm{q}^{-1}$ ) was recorded with sole pigeon pea which was significantly lower to sole finger millet (long, 
medium and short duration) as well as intercropping system. In intercropping system, minimum specific energy (418.28 $\mathrm{MJ} \mathrm{q}^{-1}$ ) was recorded with pigeon pea + finger millet (SD) 1:1 which was on a par with pigeon pea + finger millet (MD) 1:1 (428.07 $\left.\mathrm{MJ} \mathrm{q}^{-1}\right)$, pigeon pea + finger millet (LD) 1:1 (434.06 $\mathrm{MJ} \mathrm{q}^{-1}$ ), pigeon pea + finger millet (SD) 1:2 (450.64 $\mathrm{MJ} \mathrm{q}^{-1}$ ), pigeon pea + finger millet (LD) 1:2 (455.34 MJ $\mathrm{q}^{-1}$ ) and pigeon pea + finger millet (MD) 1:2 (467.94 $\mathrm{MJ} \mathrm{q}^{-1}$ ) and significantly superior than rest of the intercropping systems.

It is clear from the results that the minimum specific energy is required by legumes (pigeon pea) and higher by cereals (finger millet). In intercropping systems, specific energy is lower at $1: 1$ row ratio which was maximum at 1:4 row ratio (higher plant density of finger millet) under pigeon pea + finger millet intercropping system. Higher value of specific energy was found as the number of rows (plant density) of finger millet increases in intercropping system.

\section{References}

Kumar, B.H. Prasanna., Halikatti, S.I. and Ninganur, B.T. 2009. Sustainable intercrop association of pigeon pea (Cajanus cajan) in little millet (Panicum sumatrence L.). Karnataka Journal of Agricultural Sciences, 22(4): 887-888.

Mahto, D.K., Ahmad, S., Singh, C.S. and Srivastava, G.P. 2007. Soil fertility and nutrient uptake in finger millet (Eleusine coracana L.) based intercropping systems. Journal of Research (BAU), 19 (1): 87-90.

Maitra, S., Ghosh, D.C., Sounda, G., Jana, P.K. and Roy, D.K. 2000. Productivity, competition and economics of intercropping legumes in finger millet (Eleusine coracana) at different fertility levels. Indian Journal Agriculture Science., 70(12): 824-8.

Padhi, A.K. and Panigrahi, R.K. 2006. Effect of intercrop and crop geometry on productivity, economics, energetics and soil fertility status of maize based intercropping systems. Indian Journal of Agronomy, 51(3): 174- 177.

Panesar, B.S. and Bhatnagar, A.P. 1994. Energy norms for inputs and outputs of agriculture sector. In: Energy Management and conservation in agricultural production and food processing pp 5-16.

Ramamoorthy, K., Christopher Lourduraj, A., Alagudurai, S., Kandasamy, O.S. and Murugappan, V. 2004. Intercropping pigeon pea (Cajanus cajan) in finger millet (Eleusine coracana) on productivity and soil fertility under rainfed condition. Indian Journal of Agronomy, 49(1): 28-30.

Verma S.R. Mittal J.P. and Singh. Surendra (Eds.) USG Publishers and Distributors, Ludhiana.

Verma, U.N., Pal, S.K., Thakur, R., Singh, M.K. and Upasani, R.R. 1994. Energy production of crops and cropping systemA review paper presented in National Seminar on Agricultural Energy, held at BAU, Ranchi from October 27-28.

Willey, R.W. 1979. Intercropping - Its importance and research needs. Part I. Competition and yield advantages. Field Crop Abstracts, 32(1): 1-10.

\section{How to cite this article:}

Sunita. Kujur, Md. Naiyar Ali, R.K. Lakra and Ahmad, S. 2018. Production Potential, and Energetic Studies as Affected by Pigeon Pea (Cajanus cajan L.) and Finger Millet (Eleusine coracana L.) Intercropping System. Int.J.Curr.Microbiol.App.Sci. 7(01): 2509-2517. doi: https://doi.org/10.20546/ijcmas.2018.701.301 